\title{
Energy saving and reduction of emissions in heating residential buildings in Poland - potential and selected activities
}

\author{
Piotr Lis ${ }^{1, *}$ \\ ${ }^{1}$ Czestochowa University of Technology, Faculty of Infrastructure and Environment, \\ J. H. Dąbrowskiego 73, 42-201 Częstochowa, Poland
}

\begin{abstract}
The communal and living sector, to the extent that it is the sub-sector of buildings with a majority share of residential buildings, on average, account for approximately $41 \%$ of total energy consumption in the European Union. Due to a large share in the total energy consumption, the buildings sector has a significant potential to improve the energy efficiency of existing buildings and thus significantly reduce emission of air pollutants. One way is through thermal modernization. The article presents the expected energy and environmental effects of measures which adjust the existing residential buildings to the requirements in force in Poland since 2021. It has been assumed that the energy demand for heating buildings will be limited to the level of $55 \mathrm{kWh} /\left(\mathrm{m}^{2}\right.$ year) for multifamily residential buildings and $60 \mathrm{kWh} /\left(\mathrm{m}^{2}\right.$ year $)$ for single-family residential buildings. The calculations show that it is possible to reduce energy consumption for heating of residential buildings by over $70 \%$, which will result in a reduction of the total air pollutant emissions from housing heating, in relation to the situation in 2011. The article indicates existing reserves in thermal modernization activities and related problems based on the analysis of selected parameters of residential buildings.
\end{abstract}

\section{Introduction}

Recent years have seen two dominant and interdependent trends in the discussion of economic development problems:

- increase in demand for energy resulting from development with simultaneous depletion of non-renewable fuels and searching for sources to meet the growing needs,

- emission of pollutants.

In view of a constant increase in energy demand, it is considered that energy efficiency can become an alternative and important source of energy and at the same time help reduce the emissions of air pollution arising in its production. The search for the greatest opportunities for energy savings and efficiency should focus on the areas where energy consumption is highest. The dominant role here is played by the communal and living sector, to the extent that it is the sub-sector of buildings with a majority share of residential buildings. Buildings, on

\footnotetext{
*Corresponding author: piolis@is.pcz.czest.pl
} 
average, account for approximately $41 \%$ [1,2] of total energy consumption in the European Union. Buildings built at different times, according to different existing typical construction solutions and thermal and energy requirements introduced for some time now, have different energy performances. On average, these performances differ significantly from the contemporary standards in this respect. This is the reason for the predominant share of energy consumption for space heating in the overall energy consumption of buildings and the direct reason for their relatively high operational energy intensity. The most important purpose of energy use in households in Poland was space heating, the share of which was $66.4 \%$ in 2016 [3]. Solid fuels and district heating are clearly dominant in space heating [4].

The quoted data only strengthen the thesis that reducing energy consumption in buildings is very important for rational energy management and reducing emissions of pollutants into the air. Residential buildings play a dominant role in this process and have therefore been the subject of particular attention by the author of this publication.

\section{Aim, definitions and methods}

The aim of the presented material was to estimate the possibilities of reducing energy consumption for heating residential buildings and thereby reduce emissions of air pollutants in the whole country. The article presents the expected energy end ecological effects of measures limiting the $\mathrm{EK}_{\mathrm{H}}$ index - the final energy consumption values for heating residential buildings to the level of $55-60 \mathrm{kWh} /\left(\mathrm{m}^{2}\right.$.year $)$. The explanations of the index type and its values are presented below.

In Poland, the methodology of determining the energy performance of a building has been presented in the Regulation of the Minister of Infrastructure and Development on the methodology of determining the energy performance of a building or a part of a building and energy performance certificates [5]. The basic value used to determine the index of energy performance of residential buildings, $E_{\mathrm{PH}+\mathrm{W}}$, is here the calculated value of $\mathrm{Q}_{\mathrm{p}}-$ annual non-renewable primary energy demand for technical systems in $\mathrm{kWh} /$ year. The methodology for calculating this figure includes heating, cooling and ventilation systems, hot water production, permanently installed lighting (so-called built-in lighting), which form the so-called energy use objectives to be taken into account in the methodology of energy performance of buildings. In the case of residential buildings, built-in lighting is usually not present.

In the article, the main attention is paid to heating a building. For this reason, the basic figure from which the discussion has started is $\mathrm{Q}_{\mathrm{p}, \mathrm{H}}-$ annual demand for non-renewable primary energy for the heating system. It is calculated taking into account the coefficient of non-renewable primary energy input for the production and supply of a carrier of energy or energy for heating $\mathrm{w}_{\mathrm{H}}$. The value of this coefficient largely depends on the energy policy of the state and distorts the physical dimension of the size of $\mathrm{Q}_{\mathrm{p}, \mathrm{H}}$. For this reason, the calculated value of $\mathrm{Q}_{\mathrm{p}, \mathrm{H}}$ cannot be compared with the calculated energy demand or the measured energy consumption for heating $\mathrm{C}_{\mathrm{H}}$. With this in mind, it has been decided that in the present case the value to be used would be that determined as $\mathrm{EK}_{\mathrm{H}}$ index for the annual final energy demand for building heating, which is the quotient of the annual final energy demand delivered to the building for the heating system $\mathrm{Q}_{\mathrm{k}, \mathrm{H}}$ and the area of the building with controlled air temperature (heated or cooled area) $\mathrm{A}_{\mathrm{f}}$.

In addition, attention should be paid to the use of the aforementioned energy demand for the energy performance of buildings. These are calculated values and should be included in the theoretical ones. The exception is the use for energy performance of energy consumption that is the actual quantity that is obtained by direct or indirect measurement. In the case of GUS statistics on space heating, they refer to the energy consumption for this purpose (actual value) and not to the energy demand (theoretical value). The latter concept 
is undefined and absent from the GUS studies, e.g. [6]. Correctly calculated values of the annual demand of $\mathrm{Q}_{\mathrm{k}, \mathrm{H}}$ and the related $\mathrm{EK}_{\mathrm{H}}$ index should be as close as possible to the value of the annual energy consumption of $\mathrm{C}_{\mathrm{H}}$ and the related unitary annual final energy consumption index for the heating of a building designated as $\mathrm{EK}_{\mathrm{CH}}$. The $\mathrm{EK}_{\mathrm{CH}}$ index is the quotient of the annual final energy consumption supplied to a building for the heating system $\mathrm{C}_{\mathrm{H}}$ and the area of the building with controlled air temperature (heated area) $\mathrm{A}_{\mathrm{f}}$. Due to the availability of statistical data, the calculation simplifies the assumption that the area of a building or flat with controlled air temperature (heated area) $A_{f}$ is equal to the usable area $A_{U}$.

The range of index $\mathrm{EK}_{\mathrm{H}}$ values $\left(55-60 \mathrm{kWh} /\left(\mathrm{m}^{2} \cdot\right.\right.$ year $)$ ) indirectly results from the fact that since 2021 Poland will be subject to a requirement concerning the maximum value of the $\mathrm{EP}_{\mathrm{H}+\mathrm{W}}$ index of the annual calculation demand of a building for non-renewable primary energy for heating and hot water production at the level of $65 \mathrm{kWh} /\left(\mathrm{m}^{2}\right.$ year $)$ for multi-family residential buildings and $70 \mathrm{kWh} /\left(\mathrm{m}^{2}\right.$ year) for single-family residential buildings [7]. In the presented analyses, the baseline value for their conduct was the already mentioned $\mathrm{EK}_{\mathrm{H}}$ coefficient of final energy consumption for heating, i.e. a value that does not take into account the energy consumption for hot water production. For this reason, the range of its values obtained after reducing the $\mathrm{EP}_{\mathrm{H}+\mathrm{W}}$ index by $10 \mathrm{kWh} /\left(\mathrm{m}^{2} \cdot\right.$ year $)$ has been assumed. In a simplified way, it was assumed that such a value would correspond to the energy consumption for hot water production.

Considerations and analyses carried out later in this paper refer to the year 2011 due to the fact that in that year the National Census (abbreviated to NSP 2011) was conducted. Details of the statistical research methodology applied by the Central Statistical Office are described at the beginning of each source item with the data of the Central Statistical Office used by the author of the article, and additionally in [6]. For air pollutant emissions, the available output data is for households, not for residential buildings. For this reason, it was necessary to introduce the concept of a household to the considerations. Group of people living together in an apartment and jointly maintaining themselves [8].

The aforementioned data were searched and identified in terms of their suitability for the previously formulated purpose of the presented analysis and were the basis for the conducted estimates.

\section{Energy characteristics of residential buildings}

In 2011, there were 6,047,100 buildings with at least one flat in Poland, of which 5,542,600 were residential [9]. The main focus is on the group of occupied and heated dwellings, and in principle on the dwellings located there, as they contribute to the analyzed energy consumption for space heating. There were 5,182,330 such facilities in Poland. The quantitative characteristics of the buildings and apartments located there are presented in Table 1.

In this time, there were 12,060,000 apartments in occupied and heated residential buildings with a usable area $868 \mathrm{mln} \mathrm{m}^{2}$ (484 $\mathrm{mln} \mathrm{m}^{2}$ in single-family and $384 \mathrm{mln} \mathrm{m}^{2}$ in multi-family buildings) [9, 12]. 4,81 million of these apartments were in single-family buildings and 7.25 million in multi-family buildings $[9,12]$. These apartments were used by $13,568,000$ households $[9,10]$. Energy consumption in households (including passenger cars in operation) reached the level of $1117 \mathrm{PJ}$ [11] with the dominant share of heating amounting to $68.8 \%$ [11]. "In terms of volume, solid coal fuels and district heating, which is also produced from these fuels in approx. $75 \%$, played a leading role in space heating" [11].

The buildings under consideration were constructed in different periods with different technical requirements for their design and construction. Of particular importance from the point of view of the energy consumption for heating buildings are the regulations concerning heat protection requirements at the beginning and, more recently, energy efficiency. 
The energy performance of the buildings and apartments located there are presented in Table 2 and Table 3.

Table 1. Occupied and heated buildings and apartments constructed in Poland in various periods.

\begin{tabular}{|c|c|c|c|c|c|c|c|c|}
\hline \multirow[t]{2}{*}{$\begin{array}{c}\text { The } \\
\text { construction } \\
\text { period }\end{array}$} & \multicolumn{2}{|c|}{$\begin{array}{c}\text { Occupied } \\
\text { and heated } \\
\text { buildings [9] }\end{array}$} & \multicolumn{2}{|c|}{$\begin{array}{c}\text { Occupied } \\
\text { apartments } \\
\text { in occupied } \\
\text { and heated } \\
\text { buildings [10] }\end{array}$} & \multicolumn{2}{|c|}{$\begin{array}{c}\text { Usable area } \mathrm{A}_{\mathrm{U}} \\
\text { occupied apartments } \\
\text { in occupied } \\
\text { and heated } \\
\text { buildings [12] }\end{array}$} & \multirow{2}{*}{$\begin{array}{c}\begin{array}{c}\mathbf{E} K_{\mathbf{H}+\mathbf{W}} \\
{[\mathbf{1 3}]}\end{array} \\
\begin{array}{c}\mathrm{kWh} / \\
\left(\mathrm{m}^{2} \cdot \mathrm{year}\right)\end{array} \\
\end{array}$} & \multirow{2}{*}{$\begin{array}{c}\begin{array}{c}\mathbf{E K}_{\mathrm{CH}} \\
(\text { own } \\
\text { elaboration } \\
\text { based on } \\
[10,12,14])\end{array} \\
\begin{array}{c}\mathrm{kWh} / \\
\left(\mathrm{m}^{2 \cdot} \text { year }\right)\end{array} \\
\end{array}$} \\
\hline & Thous. & $\%$ & $\mathrm{mln}$ & $\%$ & Thous. $\mathrm{m}^{2}$ & $\%$ & & \\
\hline before 1918 & 404.61 & 7.81 & 1.12 & 9.25 & 68346.09 & 7.87 & $>300$ & 321.89 \\
\hline 1918-1944 & 809.22 & 15.61 & 1.39 & 11.54 & 94086.82 & 10.84 & $260-300$ & 255.08 \\
\hline 1945-1970 & 1363.48 & 26.31 & 3.02 & 25.05 & 182847.98 & 21.06 & $220-260$ & 224.23 \\
\hline 1971-1978 & 654.03 & 12.62 & 2.03 & 16.84 & 127816.06 & 14.72 & $190-220$ & \multirow{2}{*}{197.59} \\
\hline 1979-1988 & 753.79 & 14.55 & 2.12 & 17.57 & 160657.69 & 18.51 & $140-190$ & \\
\hline 1989-2002 & 670.65 & 12.94 & 1.47 & 12.16 & 134916.96 & 15.54 & $125-160$ & \multirow{3}{*}{157.90} \\
\hline 2003-2007 & 321.47 & 6.20 & 0.55 & 4.57 & 59469.97 & 6.85 & \multirow{2}{*}{$90-120$} & \\
\hline 2008-2011 & 205.08 & 3.96 & 0.36 & 3.01 & 39942.52 & 4.60 & & \\
\hline Total & 5182.33 & 100.00 & 12.06 & 100.00 & 868084.10 & 100.00 & 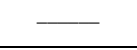 & 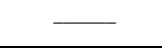 \\
\hline
\end{tabular}

Table 2. Index of energy consumption for heating of occupied and heated buildings and apartments used in Poland to 2011 inclusive (own elaboration based on $[9,12,14,15]$ ).

\begin{tabular}{|c|c|c|c|}
\hline \multirow{2}{*}{ Quantity } & \multicolumn{2}{|c|}{ Index of energy consumption for heating } & $\begin{array}{c}\text { Index of energy } \\
\text { consumption for heating }\end{array}$ \\
\cline { 2 - 4 } & in single-family buildings & in multi-family buildings & $\mathrm{kWh} /\left(\mathrm{m}^{2} \cdot\right.$ year $)$ \\
\cline { 2 - 4 } & $\mathrm{kWh} /\left(\mathrm{m}^{2} \cdot\right.$ year $)$ & $\mathrm{kWh} /\left(\mathrm{m}^{2} \cdot\right.$ year $)$ & 208.51 \\
\hline Weighted average & 243.94 & 163.91 & \\
\hline
\end{tabular}

Table 3. Energy consumption for heating of occupied and heated buildings and apartments used in Poland to 2011 inclusive (own elaboration based on $[9,12,14,15]$ ).

\begin{tabular}{|c|c|c|c|}
\hline \multirow{2}{*}{ Quantity } & \multicolumn{2}{|c|}{ Energy consumption for heating } & \multirow{2}{*}{$\begin{array}{c}\text { Energy consumption } \\
\text { for heating }\end{array}$} \\
\cline { 2 - 3 } & in single-family buildings & in multi-family buildings & TWh/year \\
\cline { 2 - 3 } & TWh/year & TWh/year & 181 \\
\hline \multirow{2}{*}{ Total } & 118 & 63 & \\
\hline
\end{tabular}

\section{Energy saving in heating residential buildings and reduction of air pollutant emissions from households}

The energy efficiency potential of existing buildings is very high, especially used for space heating. An analysis of the potential for reducing energy consumption for heating residential buildings which were in operation in Poland in 2011 with a reduction of the unit value of annual energy consumption for heating to the level of $60 \mathrm{kWh} /\left(\mathrm{m}^{2} \cdot\right.$ year $)$ for multi-family buildings and $55 \mathrm{kWh} /\left(\mathrm{m}^{2}\right.$.year) for single-family buildings was carried out.

Due to the energy consumption for heating in these buildings, attention was focused on occupied and heated residential buildings, of which there were 5,182,330. A simplifying 
assumption has been made that the usable area is the heated area. The calculations used a simplified methodology and were based on the data concerning the total energy consumption for heating in buildings and usable areas of apartments located there in. The differences between these calculated values of specific annual energy consumption and the previously adopted levels of reduction to $55 \mathrm{kWh} /\left(\mathrm{m}^{2} \cdot\right.$ year $)$ and $60 \mathrm{kWh} /\left(\mathrm{m}^{2} \cdot\right.$ year $)$ were the basis for estimating the energy saving potential in this respect presented in Table 4.

Table 4. Energy saving potential for heating residential buildings as a result of reduction of specific energy demand for heating to the level of $60 \mathrm{kWh} /\left(\mathrm{m}^{2} \cdot\right.$ year) for single-family buildings, $55 \mathrm{kWh} /\left(\mathrm{m}^{2} \cdot\right.$ year $)$ for multi-family buildings.

\begin{tabular}{|c|c|c|c|c|c|}
\hline \multicolumn{3}{|c|}{ Reduction of energy consumption for heating } & \multicolumn{2}{c|}{$\begin{array}{c}\text { Reduction of total energy } \\
\text { consumption for heating }\end{array}$} \\
\hline in single-family buildings & \multicolumn{2}{|c|}{ in multi-family buildings } & & TWh & $\%$ \\
\hline TWh & $\%$ & TWh & $\%$ & TWh & 72.29 \\
\hline 88.98 & 75.40 & 41.86 & 66.45 & 130.84 & \\
\hline
\end{tabular}

Table 5. Annual reduction of air pollutant emissions from the heating and the total in households (own elaboration based on $[16,17]$ ).

\begin{tabular}{|c|c|c|c|}
\hline Specification of emission & $\begin{array}{c}\text { Reduction of air } \\
\text { pollutant } \\
\text { emissions } \\
\text { from household } \\
\text { due to reduction } \\
\text { of energy demand } \\
\text { for heating } \\
\text { in households } \\
\text { (thousand tons) }\end{array}$ & $\begin{array}{c}\text { Reduction of air } \\
\text { pollutant emis. } \\
\text { from household } \\
\text { due to reduction } \\
\text { of energy demand } \\
\text { for heating } \\
\text { in relation } \\
\text { to air pollutant } \\
\text { emissions } \\
\text { from household } \\
(\%) \\
\end{array}$ & $\begin{array}{c}\text { Reduction of air } \\
\text { pollutant emis. } \\
\text { from household } \\
\text { due to reduce } \\
\text { of energy demand } \\
\text { for heating } \\
\text { in relation to } \\
\text { total air pollutant } \\
\text { emissions in Poland } \\
(\%)\end{array}$ \\
\hline \multicolumn{4}{|c|}{ AIR EMISSIONS FOR GREENHOUSE GAS EXPRESSED CARBON DIOXIDE EQUIVALENT } \\
\hline Emission of carbon dioxide $\mathrm{CO}_{2}$ & 35738.35 & 57.12 & 10.82 \\
\hline Emission of nitrous oxide & 202.81 & 46.54 & 0.74 \\
\hline Emission of methane & 1835.16 & 71.33 & 5.16 \\
\hline \multicolumn{4}{|c|}{ AIR EMISSION OF SELECTED POLLUTANTS } \\
\hline Emission of nitrogen oxides $\mathrm{NO}_{\mathrm{x}}$ & 48.80 & 41.55 & 5.74 \\
\hline Emission of sulfur oxides $\mathrm{SO}_{\mathrm{x}}$ & 158.44 & 72.29 & 17.41 \\
\hline Emission of ammonia $\mathrm{NH}_{3}$ & 0.37 & 45.03 & 0,14 \\
\hline $\begin{array}{l}\text { Emission of non-methane volatile } \\
\text { organic compounds }\end{array}$ & 74.29 & 32.38 & 11.39 \\
\hline Emission of carbon monoxide $\mathrm{CO}$ & 1172.69 & 62.59 & 40.22 \\
\hline Dust emission $\mathrm{PM}_{10}$ & 75.00 & 68.26 & 30.58 \\
\hline Dust emission $\mathrm{PM}_{2,5}$ & 44.35 & 66.37 & 29.29 \\
\hline Emission of total suspended dust & 119.35 & 67.55 & 26.58 \\
\hline Emis. of dioxins and furans, i-TEQ & 97.51 & $\mathrm{x}$ & 36.25 \\
\hline Emis. of hexachlorobenzene (HCB) & 2.02 & $\mathrm{x}$ & 14.88 \\
\hline Emis. of polychlor. biphenyls (PCB) & 0.000315 & $\mathrm{x}$ & 43.43 \\
\hline $\begin{array}{c}\text { Emission of polycyclic aromatic } \\
\text { hydrocarbons }\end{array}$ & 0.09 & $\mathrm{x}$ & 61.86 \\
\hline
\end{tabular}


The analysis of the possibilities to reduce the energy consumption for heating residential buildings and pollutant emissions inherent thereto in relation to the energy use objectives of buildings clearly shows the greatest potential for measures taken in the scope of space heating. In the next step, a percentage reduction of the total energy demand for heating of the buildings under consideration was assumed at the calculated average level of $72.29 \%$. This value allowed for a simplified calculation of the reduction of emissions of selected pollutants to the air as a result of the reduction of energy demand for heating buildings by raising their energy standard (Table 5).

For the calculations, a simplified assumption was made that the percentage reductions in energy demand and pollutant emissions were equal. The calculations were carried out starting from the elaboration of the obtained data concerning the emission of selected pollutants to the air from heating and total in households, and ending with their percentage reduction resulting from the previously calculated reduction of energy demand for heating. Table 5 presents only the results of the last stage of calculations for households in 2011 in the form of reduction of the types of emissions to the air considered in the work as a result of reduction of energy demand for heating.

\section{Summary}

In the methodology of calculations carried out there are, of course, many simplifications which affect the accuracy of estimations. However, due to the aim of the article, they do not introduce any significant distortions to the estimated energy saving potential for heating residential buildings as a result of increasing the thermal insulation of their envelope components.

Simple calculations show that as a result of adjusting the energy demand for heating in residential buildings to the level of $50-60 \mathrm{kWh} /\left(\mathrm{m}^{2}\right.$ year $)$, the demand in existing residential buildings may be reduced by an average of approx. $72.3 \%$ as compared to the situation in 2011. For single-family buildings these savings amounted to $75.4 \%$, and for multi-family buildings to $66.4 \%$. The disclosed disproportion between single and multi-family housing is caused by higher financial resources allocated in thermal modernization programs for multi-family residential buildings. The potential for annual energy savings in terms of the analyzed reduction of its consumption to heat buildings was $130.8 \mathrm{TWh} /$ year. Considering that in 2014 the total final energy consumption in Poland amounted to 531.4 TWh [18], the estimated energy savings account for $24.6 \%$ of the said consumption.

The analysis of the possibilities to reduce the energy consumption for heating residential buildings in relation to the energy use objectives of buildings clearly shows the greatest potential for measures taken in the scope of space heating.

In terms of thermo-modernization measures, there are large reserves, as indicated in the report prepared by the Central Statistical Office in 2018 [19].This report includes a synthetic overview of results of the survey "Development of methodology and realisation of a survey of a scale of thermo-modernization activity in multi-dwelling residential buildings in order to improve their energy consumption and estimation of needs and plans in this area" including major regional diversifications. Data presented in this report concern only 189,289 buildings (among 5,182,330 occupied and heated buildings [9]) and detailed data about thermo-modernization realized in 2010-2016 (via electronic questionnaire) for 11928 buildings, the real possibilities in the discussed area are much larger. The replacement of the heat source for heating systems using coal fuels with a source using gaseous fuels will further increase the efficiency of the entire heating system, increasing the obtained energy and environmental effect. The third place among energy carriers used for this 
purpose was natural gas. It was used by $10 \%$ of households, including $9.2 \%$ of households as the basic carrier [11].

Achieving reduction of the unit value of annual energy consumption for heating to the level of $60 \mathrm{kWh} /\left(\mathrm{m}^{2}\right.$ year) for multi-family buildings and $55 \mathrm{kWh} /\left(\mathrm{m}^{2}\right.$.year $)$ for singlefamily buildings it will be impossible without the modernization of the ventilation system with the use of heat recovery. The mechanical ventilation and air conditioning were used only in around $4 \%$ of residential buildings [11] and the modernization or replacement of ventilation systems in $5.6 \%$ of residential buildings [19]. The use of unconventional energy sources for heating also shows large reserves because the conducted study shows that heat pumps were used for heating purposes only by $0.08 \%$ of households, including space heating by $0.07 \%$ [11].

At the same time, such measures will reduce the overall emissions of air pollutants from households due to the reduction of energy demand for heating of apartments from about $30 \%$ to about $70 \%$ (Table 5), depending on the type of pollutant. In the scale of the whole country, this will reduce the air pollutant emissions considered in this paper from about $0.7 \%$ to about $62 \%$ (Table 5) in comparison to the national emissions of these pollutants in 2011. It should also be noted that the low percentage reduction for domestic emissions is mainly due to the low share of these household emissions in the total Polish air emissions account. Reduced energy consumption for heating also means lower costs and thus an economic effect. This can significantly affect the availability of an efficient and environmentally friendly heating system. Its cost and reduced heat demand, together with significantly reduced heating costs, may be more attractive for a larger number of residents. This will help to reduce the recent phenomenon of energy poverty. However, the achievement of the estimated results in a satisfactory scale and over time should be the subject of far-reaching state intervention.

The material was prepared as part of the statutory research of the Czestochowa University of Technology BS/PB-401-301/18 task 6 .

\section{References}

1. Sz. Peryt, B. Asztemborski, Efektywność wykorzystania energii w latach 2004-2014 (GUS Departament Produkcji, Krajowa Agencja Poszanowania Energii S.A., Warszawa, 2016)

2. P. Lis, Cechy budynków edukacyjnych a zużycie ciepła do ogrzewania (Seria Monografie nr 263, Wydawnictwo Politechniki Częstochowskiej, Częstochowa, 2013)

3. Sz. Peryt, R. Wnuk, G. Berent Kowalska, K. Walkowska, Efektywność wykorzystania energii w latach 2006-2016 (GUS Departament Przedsiębiorstw, Krajowa Agencja Poszanowania Energii S.A., Warszawa, 2018)

4. W. Tkaczyk, A. Kozieł, H. Mikołajuk, Zużycie energii w gospodarstwach domowych w 2012 r. (GUS Departament Produkcji, Ministerstwo Energii, Agencja Rynku Energii S.A., ARE S.A., Warszawa, 2012)

5. Rozporządzenie Ministra Infrastruktury i Rozwoju z dnia 27 lutego 2015 r. w sprawie metodologii wyznaczania charakterystyki energetycznej budynku lub części budynku oraz świadectw charakterystyki energetycznej (Dz.U. 2015 poz. 376, Warszawa, 2015)

6. G. Kacperczyk, H. Mikołajuk, R. Gilecki, H. Hassman-Udrycka, J. Kacprowska, G. Parciński, M. Szymańska, Zasady metodyczne sprawozdawczości statystycznej $z$ zakresu gospodarki paliwami i energia oraz definicje stosowanych pojęć (GUS Departament Statystyki Gospodarczej, Warszawa, 2006)

7. Obwieszczenie Ministra Infrastruktury i Rozwoju z dnia 17 lipca 2015 r. w sprawie ogłoszenia jednolitego tekstu rozporządzenia Ministra Infrastruktury w sprawie 
warunków technicznych, jakim powinny odpowiadać budynki i ich usytuowanie, (Dz.U. 2015 poz. 1422 z późniejszymi zmianami)

8. Główny Urząd Satystyczny. Portal informacyjny. Pojęcia stosowane $w$ statystyce publicznej (Access to the website: stat.gov.pl/metainformacje/slownik-pojec/pojeciastosowane-w-statystyce-publicznej/103,pojecie.html (01.03.2019) (GUS, Warszawa, 2019)

9. A. Matulska-Bachura, K. Andrusiuk, A. Dec, E. Knyszewska, M. Przybylska, B. Różańska, M. Sobczyk, Mieszkania. Narodowy Spis Powszechny Ludności i Mieszkań 2011 (including file: PBS_nsp2011_mieszkania.xls. (Access to the website: https://stat.gov.pl/spisy-powszechne/nsp-2011/nsp-2011-wyniki/mieszkania-narodowyspis-powszechny-ludnosci-i-mieszkan-2011,18,1.html)) (GUS, Warszawa, 2011)

10. A. Matulska-Bachura, K. Andrusiuk, A. Dec, E. Knyszewska, M. Przybylska, B. Różańska, M. Sobczyk, Zamieszkane budynki. Narodowy Spis Powszechny Ludności i Mieszkań 2011 (including file: L_zamieszk_budynki_nsp_2011.xls. (Access to the website: https://stat.gov.pl/spisy-powszechne/nsp-2011/nsp-2011-wyniki/zamieszkane-budynkinsp-2011,15,1.html)) (GUS, Warszawa, 2011)

11. W. Tkaczyk, A. Kozieł, H. Mikołajuk, Zużycie energii w gospodarstwach domowych w 2015 r. (GUS Departament Produkcji, Ministerstwo Energii, Agencja Rynku Energii S.A. (ARE S.A., GUS, Warszawa, 2015)

12. A. Matulska-Bachura, K. Andrusiuk, E. Knyszewska, M. Przybylska, B. Różańska, M. Sobczyk, Warunki mieszkaniowe gospodarstw domowych i rodzin. Narodowy Spis Powszechny Ludności i Mieszkań 2011 (GUS, Warszawa, 2014)

13. S. Mańkowski, E. Szczechowiak, Zintegrowany system zmniejszenia eksploatacyjnej energochtonności budynków. Strategiczny projekt badawczy, Zadanie badawcze nr 2. Tom I, część A: Uwarunkowania przekształceń w budownictwie (Warszawa, Poznań, 2013)

14. P. Lis, E3S Web of Conferences 49, 00068 (2018)

15. D. Ürge-Vorsatz, E. Wójcik-Gront, S. Tirado Herrero, E. Labzina, P. Foley, Impact on the labour market of the deep energy modernization program of buildings in Poland (The Center for Climate Change and Sustainable Energy Policy, European Climate Foundation, Central European University, Budapest, 2012)

16. D. Bochenek, M. Bancarzewska, A. Górska, K. Karczewska, M. Lizuraj, T. Pawłowska, A. Reńska, J. Sulik, M. Wojciechowska, A. Wrzosek, K. Zagórska, K. Zieleźny, Ochrona środowiska (GUS, Warszawa, 2013)

17. Departament Badań Regionalnych i Środowiska GUS, Rachunki ekonomiczne środowiska. GUS. Notatka informacyjna. Załacznik nr 1 Rachunki emisji do powietrza (Access to the website: http://stat.gov.pl/obszary-tematyczne/srodowisko-energia/ srodowisko/rachunki-ekonomiczne-srodowiska,7,1.html (12.04.2017)) (GUS, Warszawa, 2016)

18. Departament Produkcji GUS, Wydział Bilansów Paliw, Surowców i Materiałów, Energia (Access to the website: https://stat.gov.pl/files/gfx/portalinformacyjny/pl/ defaultaktualnosci/5485/1/4/1/ energia2016.pdf) (GUS, Warszawa, 2016)

19. M. Kowalska, K. Markowski, Z. Kurlej, I. Włosińska, B. Cebula, T. Gałązka, P. Gradzik, L. Hinz, B. Jędrzejewska, J. Kobylarz, A. Malinowska, J. Malinowski, Sz. Marchewka, A. Nocko, A. Polakr, A. Powęska, E. Wodzyńska, Centrum Badań i Edukacji Statystycznej GUS, Opracowanie metodologii i przeprowadzenie badania skali działań termomodernizacyjnych budynków mieszkalnych wielomieszkaniowych $w$ celu poprawy ich energochłonności oraz ocena potrzeb i planowanych działań $w$ tym kierunku (GUS, Warszawa, 2018) 